\title{
INSIDE THE “PUZZLE” OF CONTEMPORARY INDONESIA'S REGIONAL AUTONOMY POLICY
}

\author{
Syarif Hidayat ${ }^{1}$
}

\begin{abstract}
This paper endeavours to see the nature of Indonesian decentralisation and regional autonomy more on the basis of micro level perspective. While most of the previous studies have relied heavily on macro level perspective, such as-assessing how central government has initiated the idea of decentralisation and regional autonomy, investigating the extent to which power has been distributed to the regions, and exploring central government's controls over the regions-the material presented in this paper has been focussed more on exploring how local state elites themselves have seen decentralisation and regional autonomy. Based on a series of primary data collected in four research locations (the province of West Java, West Sumatra, West Kalimantan, and East Nusa Tenggara/NTT), the author has subsequently ended up with a proposition which says that: the puzzle of contemporary Indonesia's regional autonomy policy must be understood on the basis of so called local state elites ambivalence orientation towards decentralisation and regional autonomy policies. The research findings suggested that local state elites had officially manipulated that of ambivalence orientation as the stated justification for their misconduct behaviour in implementing decentralisation and regional autonomy policies. Eventually, the author argues, amongst the distinctive contribution of this paper to the academic development is that it share the work of those who have endeavoured to conceptualise the characteristics of decentralisation and regional autonomy in an epoch the so called "transition towards democracy".
\end{abstract}

Key words: Decentralisation, Regional Autonomy, Local State Elites, Democratic Transition

\section{Introduction}

This paper has been developed on the basis of a study entitled: "Exploring IndonesianLocalState-Elite'sOrientationTowards RegionalAutonomy”.Ingeneral terms, this study attempts to explore Indonesia's local state elite's perception of decentralisation and regional autonomy. In so doing, it has been guided by an argument that says: to have a better understanding of how decentralisation and regional autonomy has been exercised in practical terms, scholars should pay more attention to the way in which local state elite's shared norms and consent of decentralisation and regional autonomy have been developed.

${ }^{1}$ Dr. Syarif Hidayat, MA, APU, is a senior researcher at the Indonesian Institute of Sciences (LIPI), completed his Master Leading to PhD at the Department of Asian Studies, Flinders University, Adelaide, Australia (1999). His article has been reviewed by Dr. Nana Supriatna, M.Ed (Universitas Pendidikan Indonesia), and Dr. Agus Mulyana (Universitas Pendidikan Indonesia). 
The material presented in this paper, however, will be focussed more on assessing two main issues, namely: local state-elite's perspectives on power relationship between central and local governments; and its interplay with the "puzzle" of contemporary Indonesia's regional autonomy policy.

Central-local government power relationship remains crucial to be discussed since it has constituted the basic concept for decentralisation itself. In other words, the characteristic of decentralisation and regional autonomy applied in each country is determined, amongst other things, by the feature of power division between central and local governments. One may point to, for instance, political decentralisation, administrative decentralisation, wider regional autonomy, and limited regional autonomy. All of these are determined by the extent to which power and authority are assumed by a local government. The characteristic of central-local governments power relationship has been accounted by scholars as one of the key factors to highlight the two perspectives on decentralisation: political and administrative decentralisation perspectives.

The same line of reasoning should likewise be put into place to justify as to why investigating the local state-elite's perspective on regional autonomy has been considered important. In brief, it has been stated by Alagappa (1995: 28 ) that as the elite groups have greater control over power resources and are more engaged in the political process, shared norms and consent among the elite are more important than among the general public. Following Allagappa's proposition, it implies that understanding elite's perception of such a policy, including decentralisation and regional autonomy policies, remains significant. This is mainly due to, as Alagappa has put it, shared norms and consent among elite could directly or indirectly influence their behaviour, either in making or implementing such decisions. Elsewhere, Robert Bate (1981:8) puts his view as follows:

To have a better understanding about the nature of government in developing countries, scholars should pay more attention to the capacity for autonomous choice on the part of local actors, both public and private, and give greater weight to the importance of these choices in shaping the impact of external environments upon the structure of the local societies.

Although it was not stated in an explicit manner, Bate (1981) seems to have likewise given a greater weight to the importance of understanding elite's perception of such a policy, as it has become the determinant factor for elite's capacity in exercising their so called autonomous choices. A similar proposition has been made by Liddle (1996) when he attempts to describe the intercorrelation between Suharto's individual rules and Indonesian national economic policies. Even though Liddle's proposition was developed on the basis of a national perspective, it remains useful, and even relevant as a theoretical guide for understanding the interconnection between local state elite's perspective on decentralisation, on the one hand, and their behaviour in making decision, on the 
other. In brief, Liddle puts his argument as follows:

President Suharto's economic policy decisions were conditioned or influenced but not determined by four variables widely cited but often misconceived and misapplied in the Indonesian and comparativeliterature. These variables are: economic crisis; international economic forces; culture, particularly the form of leadership ideology; and regime type, specifically patrimonialism. Each, I will claim, has an impact on policy, but only as it has been filtered through President Suharto's perceptions of their nature and impact, goals for himself and his society, and calculations of how best to achieve his goals (Liddle,1996: 109).

A range of arguments stated by Bate (1981) and Liddle (1996) above, then, has been reconstructed by Hidayat (2000) to be employed as a conceptual framework for understanding the reality of Indonesia's decentralisation policy. It is in this context, Hidayat (2000) seems to have likewise given a greater weight to the importance of local state elite's perception of decentralisation as one of determinant factors for decision making process at the local government level. To put it more precisely, Hidayat argues:

Policies taken by local state elite in the implementation of decentralisation and regional autonomy have, undeniably, conditioned or influence, but not determined by central government interest. Amongst the factors which have significantly determined that of decision making process, are: local state elite's perception of the nature of decentralisation and regional autonomy; local state elite's individual and group interests; and a calculation of how best to achieve these goals (Hidayat, 2000: 92).

In appreciation of the above propositions, the importance of elites' own perception of constraints and opportunities in determining their behaviour in making such decision should be emphasised. If this argument makes sense, it is likely possible to construct an hypothesis which says: to better understand the features of Indonesian decentralisation and regional autonomy policies, scholars should pay more attention to the factors which directly or indirectly influence the behaviour of local state elite in exercising local authority. Amongst these determinant factors are local state elite's perception of decentralisation and regional autonomy policies, and the way in which this belief system has been shared with others.

Following from the above, the theoretical significance of this paper is that it attempts to see the nature of Indonesian decentralisation and regional autonomy policies more on the basis of a micro level perspective. While most of the previous studies (King, 1988; Legge, 1963; Maryanov, 1959; Mawhood, 1987; Morfit, 1986, and Rondineli, 1983) have relied heavily on a macro level perspective, such as assessing how central government has initiated the idea of decentralisation and regional autonomy, investigating the extent to which power has been distributed 
to the region, and exploring central government's controls over the regions, the focus in this paper is more on exploring how local state elite themselves have perceived the decentralisation and regional autonomy policies and processes.

Most of the primary data presented in this paper, was collected during the fieldwork in the four research sites (the province of West Java, West Sumatra, West Kalimantan, and East Nusa Tenggara/NTT). In so doing, the study relies heavily on in-depth interviews with selected informants, comprising uppermiddle officials at the structure of local bureaucracy, and members of the Local Representative Council (DPRD). The local state elite who were subjects in the study are those who are categorised as the upper-middle politic bureaucrats in the structure of local government. The reasons for choosing them to become the subjects for the study are: the local state-elite are assumed to prossess greater control over power resources and are more engaged in the political process at both the Provincial and District/City levels. The total number of local state-elite who were interviewed in the two research sites was about 376 .

The following discussion will begin with summarising the whole research finding in the four research sites, after which it will proceed to construct a generalisation regarding what the study tells us about the local state elite's perspective on, and the "puzzle" of current Indonesia's regional autonomy policy. Subsequently, some final remarks and theoretical implications will be presented in the last section of this paper.

\section{Research Finding Overviews}

The research finding from the four research sites may be briefly summarised as follows: First, quantitatively, there have been a variation of definitions of regional autonomy that were asserted by the local bureaucrats in the four research locations. However, when these definitions are examined on the basis of the local government structure, the study reveals that the majority of the provincial bureaucrats were inclined to define regional autonomy as "the authority assumed by a local government to manage its own household". On the other hand, a greater number of district bureaucrats have preferred to define regional autonomy as "the authorities assumed by a local government to determine its own destiny".

A similar phenomenon has likewise taken place in the context of local politicians. The study indicates that there have, indeed, been a series of definitions of regional autonomy stated by the local politicians in the four research sites. However, when we scrutinise the intensity of such definitions, the result of indepth interviews reveal that the majority of Provincial Politicians have favoured to articulate the regional autonomy as " $a$ limited freedom assumed by a local government in managing its own household". Meanwhile, a greater number of the District Politicians have preferred to define the regional autonomy as " $a$ wide authority assumed by a local government to manage its own household". 
Second, local state elite's conception regarding the definition of decentralisation and regional autonomy, undeniably, had a great impact on their perceptions of the main goals of decentralisation and regional autonomy themselves. This has been proven through the in-depth interviews which had revealed that the majority of local bureaucrats and politicians in the four research sites have emphasised more on the administrative and economic goals, rather than on political goals. For example, it was repeatedly asserted by the resource persons that the main goals for decentralisation ought to embody the social welfare concept and to bring government services closer to society. This line of reasoning regarding the goals of decentralisation and regional autonomy was articulated by local bureaucrats and politicians. Many of them considered these goals to be more important than others. Amongst other things, it was contended that the realisation of the social welfare concept and the development of better services ought to be the central aims behind the establishment of a nation-state. To bring these goals into reality, according to the resource persons, should be the main function of both the central and local governments. Thus, decentralisation and regional autonomy, in addition, have been valued as the instruments for attaining improved social welfare deals and better service delivery. The point to be emphasised here is that political goals of decentralisation and regional autonomy seem to have received less attention from local bureaucrats and politicians interviewed in the two research locations.

Third, the in-depth interviews indicate that the majority of bureaucrats and politicians interviewed, both at the provincial and district levels, believe that "the formulation of power relations between central and local government as stated in Law number 22 of 1999- which has subsequently been revised to become Law No. 32 of 2004-is much better than what had been formulated in the previous local government law (Law number 5 of 1974). One of the reasons mentioned in support of this statement is: "because the formulation of centrallocal governments power relations in the current law gives wider authority to the regions".

However, it is important to note here that in a few cases, there were resource persons who had different perspectives regarding the power relationship between central and local governments. For example, it has been asserted that "the formulation of central-local governments power relationship as stated in the current law has a federalist nuance, and this can endanger national integrity". Meanwhile, there is also a second opinion which states that, "the formulation of power relationship between the central and local governments as stated in the current law tends to threaten national integration since it gives a very wide authority to the regions". Ironically, these two opinions were mostly stated by provincial bureaucrats and politicians in the two research locations.

Fourth, The study suggests that there has been a number of obstacles standing in the way of decentralisation and regional autonomy and these had been asserted by the local state elite in the four research sites. However, if 
we further explore the nature of those obstacles, almost all resource persons interviewed tend to give more attention to the aspect of policy implementation, i.e. technical problems faced in the implementation of the decentralization and regional autonomy policies. Meanwhile, the conceptual aspect of the policy, that is conceptual problems relating to the decentralization and regional autonomy policies, only receive limited attention from the resource persons.

Among the technical problemsinimplementing decentralization and regional autonomy policies stated by the resource persons in the four research locations are: a) the struggle for group's interest remains dominant, b) socialization of the newly reformed local government law is lacking, c) government regulation for supporting the law is late in coming, d) the central government remains half hearted in practice, and e) the local government own income (PAD) is very insignificant.

Fifth, the research findings show that, the recommendations proposed by the key informants regarding the steps to be taken to improve decentralisation and regional autonomy policies do vary from one to the other. However, among those recommendations, the ones most frequently proposed by a majority of the resource persons are: a) the necessity of complementing the current local government law with government regulations; b) the regional autonomy policy must be implemented step by step and adjusted to the capability of the regions; c) the need to clarify the scope of provincial governments' authorities; d) central government must fully support the implementation of the regional autonomy policy; and e) the scope of authorities owned by DPRD must be clearly defined.

\section{Generalisation}

Just to summarise briefly, amongst the general conclusions that can be derived from this study is that the local state elite's had two different views towards decentralisation namely: compromise and pragmatic orientations. These are the two major categories. The first view or orientation has been characterised by, for instance, the dominance of local state elite's acceptance of, on even their compromising attitude towards, the formal arrangement stated in the newly established local government laws. Meanwhile, the second orientation (pragmatic orientation) has as its main symptomatic aspect, the local state elite's critical attitude towards the newly established local government laws. However, and it is important to be noted, the local state elite's critical attitude is more likely directed towards the policy implementation aspect rather than the substance of the concept of decentralisation itself. The amalgam of these compromise and pragmatic orientations has subsequently engendered the so called local state elite's ambivalence orientation towards decentralisation and regional autonomy policies. This is, indeed, one of the key factors for understanding the "puzzle" of contemporary Indonesia's regional autonomy policy. In Indonesian terms this has been widely known as the so called otonomi kebablasan (over reacted regional autonomy). 
Infact, thelocal state elite's ambivalent orientation has eventuallyinfluenced either directly or indirectly their behaviour when executing the decentralisation and regional autonomy policies. This seems to have been undeniable. In more practical terms, the research findings suggest that local state elites in the four research locations had officially manipulated this ambivalent orientation as the stated justification for their misconduct or wrong behaviour when implementing decentralisation and regional autonomy policies.

If the above conclusions derived from the field works can be accepted, then there are at least three major points that can be underlined. These can be taken to be the research final remarks, and in turn they would become the basis for constructing some theoretical frameworks. The implications can also be highlighted.

The first point to be noted is that the local perspective on some aspects of the concept of decentralisation and regional autonomy has, somehow, shifted from the so called administrative decentralisation perspective towards the political decentralisation perspective. This seems to provide, somehow, positive tidings for the future of Indonesia's decentralisation and regional autonomy policies.

The second point is that the ambivalent position towards decentralisation and regional autonomy policies remain dominant among both the local state elite and society at large. This ambivalence has subsequently become one of the determinant factors for the genesis of maladministration in the implementation of decentralisation and regional autonomy policies. The phenomenon of the so called Otonomi Daerah Kebablasan (over-blown regional autonomy), for instance, has become another term of abuse. It has been used to label the local state elite's and society's faulty implementation of regional autonomy policies in contemporary Indonesia.

The third point concerns the dominant role of the local state elite in determining the process of policy making. Even though society has, to some extent, been involved in the process of policy making, this involvement, more likely, is limited to the representation made by a few number of society actors. In other words, it is not in the form of popular participation.

In contrast to the first point mentioned above, the second and third points seem to bring with it a somewhat sad possibility. It casts a pessimistic shadow on the future of decentralisation and regional autonomy policies in Indonesia.

\section{Theoretical Implications}

Theoretically, stemming from the points raised above, one may raise a number of questions in particular, on the nature of Local State Elite's Orientation Towards Regional Autonomy, and in general, on the characteristic of Indonesia's decentralisation policy. The subsequent discussion will endeavour to suggest answers to these questions. 
It is clear that in order to construct an appropriate theoretical framework regarding the nature of local state elite's orientation towards regional autonomy, the study should be conducted on a wider basis. It should involve more local bureaucrats and politician as the key informants, and cover more of Indonesia's provinces as the research locations. The researchers are aware of the limited materials collected so far. They might not be sufficient to form the basis for constructing a solid theoretical framework. However, without intending to conduct an academic simplification, we at the same time believe that the data and information collected have met the normal academic standard. Therefore, we would argue that the materials derived from this study may be employed as the basis for developing a better theoretical framework regarding Indonesian local state elite's perspectives on regional autonomy. Moreover, the research findings are likewise relevant enough to be utilised as the starting point to cast light on the characteristics of Indonesian decentralisation policy in a period that has been termed as a "transition towards democracy".

The first point in the concluding remarks stated above says that there is, indeed, a shifting perspective among local state elite when articulating the concept of decentralisation and regional autonomy. The shift might be minimal but exists it does. Theoretically, this tendency may be explained by referring to Almond's (1974: 43) proposition which says: although individual belief system has a strong correlation with individual political conduct, an individual belief system is a changeable value. Its existence depends much on the socialisation process assumed by each individual. Furthermore, Almond (1974) writes, amongst the socialisation agencies that may directly or indirectly play a role in shifting an individual belief system are: formal education, environment (family and other social environments), and empirical experience assumed by each person in dealing with such matter.

Elsewhere, the second point in the final remark above says that ambivalent orientation regarding the implementation of decentralisation and regional autonomy policies remains dominant among local state elites, as well as in society. Theoretically, this phenomenon occurs due to the wide gap that exists between the change that occur at the conceptual level and the shifting behaviour at the implementation level. In a more specific sense, at the conceptual level, the newly established local government law attempts to move on the long tradition of administrative decentralisation perspective towards a more political decentralisation perspective. Meanwhile at the practical level, both perception and attitude of local state actors, as well as, society is still in the framework of the New Order's established norm and values (administrative decentralisation perspective).

In fact, the local state elite's ambivalent orientation has eventually become a determinant factor for the origin of local state elite's misconduct in the implementation of decentralisation and regional autonomy policies. This seems to have been undeniable. Theoretically, Almond (1974), for instance, has clearly 
delineated the interrelation between the perception and behaviour by saying: individual belief system would significantly determine individual conducts.

Indeed, the existence of the so called local state elite's misconduct and ambivalent attitude in the implementation of decentralisation and regional autonomy policies in Indonesia is really a latest finding. Hidayat (1999: 303), for instance, has pointed out that on a day-to-day basis Indonesian decentralisation is much more characterised by bargaining and coalition-building among both state and society actors at the local level. Specifically, Hidayat puts his proposition as follows:

The features of Indonesian decentralisation policy on a day-to-day basis is far more complex than the scholarly literature on the subject suggests; it involves more bargaining and coalition-building among both state and society actors at the local level. Indeed, the tightening grip of the central government's over the regions has not necessarily limited the opportunity for local governments to enjoy more autonomy in determining their own interests. The key to understanding this phenomenon lies in the 'relative capacity' of local state elites to make autonomous choices which cannot adequately be explained by the two classical perspectives on decentralisation, namely the political and administrative perspectives (Hidayat, 1999: 315).

Hidayat himself admits honestly that the proposition he has made was developed on the basis of Bates' (1981) argument which says: to have a better understanding about the nature of government in developing countries, scholars should pay more attention to the capacity for autonomous choice o the part of local actors, both public and private, and give greater weight to the importance of these choices in shaping the impact of external environments upon the structure of the local societies (1981: 8).

Furthermore, based on his case study in West Java and West Sumatra, Hidayat (1999) has likewise recounted a number of factors that have directly or indirectly determined the capacity of local state elites for exercising autonomous choices, either in the process of policy making or policy implementation. In short, Hidayat delineates his findings as follows:

The telling factor explaining the capacity of local state elites to exercise autonomous choices is their access to accumulated political resources. Amongst other things is their skill in re-interpreting central government policies; knowledge of local problems; alliances with particular societal groups; and individual connections with central state elites. If this argument makes sense, it is now clear enough that the conflicting nature of central government policies and the dominance of Indonesian bureaucratic patrimonialism have partly contributed to the shaping of local state elites' capacity to make autonomous choices (Hidayat, 1999: 312). 
In connection with Hidayat's finding outlined above, one may record that there are at least three major factors which have directly or indirectly supported the capacity of local state elites for practising autonomous choices in both making and implementing such decisions. The first is the local state elite's skill in reinterpreting central government policies. This means that the local state elite has the knowledge and skill to find out the weaknesses of central government policies which in turn can be manipulated for the benefit of individual and client interests. The second factor is local state elite's knowledge of the local problems. Since members of the local state elite are state actors who are involved intensively in the day-to-day running of the local government, there is no doubt that they possess a more comprehensive knowledge of the local problems than those who work for the central government. However, Hidayat argues that the knowledge of local problems may also be manipulated by local state elite. The political and economic "exchange values" of the knowledge can be exploited in the pursuit of individual and group's interest vis-à-vis that of the central government. The third factor is the existence of informal alliances with particular societal groups and central state elite. These informal alliances, according to Hidayat (1999), were used by the local state elite as their political shield, as well as, the vehicle for the practice of autonomous choice with regard to the making and implementing of decisions.

If the range of propositions proposed by Bates (1981) and Hidayat (1999) outlined above can be taken into account in the context of the second concluding remark derived from our current study, it is clear enough that the local state elites' misconduct and ambivalent attitude in the implementation of decentralisation and regional autonomy policies may theoretically be credited as being part of the practice of the so called local state elites' autonomous choice. It is, therefore, legitimate enough to promote a proposition from the present study which says:

\begin{abstract}
There are at least two major factors explaining the practice of "Otonomi DaerahKebablasan"(overreactedregionalautonomy)intheimplementation of contemporary Indonesian decentralisation and regional autonomy policies. First, it is due to a range unclear formulation at the legislation level (Laws No. 22 and 2 of 1999). This has subsequently provided the opportunities, and even the rooms, for the local state elites to re-interpret any formal arrangements printed in the laws for the sake of their own interests, and for the accomplishment of their own goals. Second, it is due to the lack of control over the behaviour of local state elites. This condition has, amongst other things, led to local state elite feeling unconstrained in manipulating their knowledge of the local problems for the pursuit of their individual goals.
\end{abstract}

When we scrutinise the substance of the above preposition, it implicitly suggests that in essence, Indonesian local state elites' ambivalent orientation towards decentralisation and regional autonomy policies arises not merely as a 
result of insufficiency in the socialisation of the policies themselves. In fact it is a manifestation of the local state elite's conception of decentralisation and regional autonomy which is still dominated by the desires to perpetuate the practice of the so called autonomous choices. If it is the case, one may perhaps argue that at the practical level, the features of decentralisation and regional autonomy policies in the "post" Suharto's government is not different from those of the previous period (Suharto's New Order). This similarity has been marked by, for instance, the continued dominance of the bargaining and coalition-building practice among local state elite with regard to both decision making and implementation of policies. Meanwhile, the difference, if it must be stated, lies in the existence of more openings or chances for members of society to participate in policy implementation, as well as, to a lesser extent, in the process of policy making. Although the involvement of members of society, in this sense, is much more likely to be in the form of the participation of the so called societal elite rather than that of the popular kind.

The above thesis concerning the day-to-day characteristics of the Indonesian decentralisation and regional autonomy policies, of course, has a close relationship with the third concluding remark derived from this study, which says: even though the channel for society's participation has, to some extent, been opened, the role of local state elite remains dominant in determining the process of policy making. If this is the case, the next question then would be: could we make a claim that the features of the day-to-day Indonesian decentralisation policy suggested by the present study may be regarded as part of the characteristics of a political system in the so called period of transition towards democracy?

Theoretically, it may be argued that the remaining dominant role of state actors, and the increased opening and chance for societal participation in the process of policy making and policy implementation are amongst the main features of a political system in the so called period of transition from an authoritarian political system towards a more democratic one. Based on this theoretical understanding, Hidayat (2003: 56-59) has outlined three main characteristics of the implementation of decentralisation during a transition towards a more democratic political system.

First, the dominant role of central government in determining decentralisation policy tends to decrease. During the authoritarian regime, the central government played a predominant role in determining the process of policy making. However, in the period of transition towards democracy, the demand coming from local governments and their community have, to some extent, been taken into consideration by the power that be in the process of policy making. Nevertheless, Hidayat (2003) notes that it is important to realize that the decreasing role of central government, in this sense, is much likely to be in a quantitative dimension. This implies that qualitatively, the central government remains able to force through its interests, although this has been conducted on the basis of democratic mechanism, and has been increasingly channelled through 
an informal political process rather than a formal mechanism.

Furthermore a conflict usually takes place in the context of power division between central and local governments. On the one hand, the demand for political reform has undeniably called for dispersing of as much as possible the power and authority to local governments. On the other hand, central governments, however, seems to have been reluctant to lose its power over local governments. In contemporary Indonesia, this conflict of interest has been reflected by, for instance, the emergence of a phenomenon so called Otonomi Daerah Setengah Hati (half-hearted regional autonomy). To overcome this dilemma and to calm down the regional dissatisfaction, the central government often resorts to resource base allocation, such as by allocating central government's fund and other forms of subsidies to the local governments.

The second characteristic of decentralisation and regional autonomy practices in the so called period of transition towards democracy, Hidayat (2003) writes, is the shifting nature of the approach to the implementation of decentralisation and regional autonomy policies. The "old approach" which is developed on the basis of a monolithic perspective and dominated by the spirit of top-down, has somehow gradually shifted towards a "new approach" which is constructed on the basis of a holistic perspective, and characterised by the spirit of bottom-up. Theoretically, one consequence of this shifting approach to policy implementation is that local governments have been allowed to assume more autonomy both in making and implementing their decisions. The exercise of this autonomy, however, has a limit. It should not exceed the scope of the authorities decentralised to each local government and does not contradict the national interests. At a practical level, however, the new approach to the implementation of the decentralisation policy was not automatically followed by the local state elite who are in charge of the local governments on a day-to-day basis. As a result it is not surprising that an ambivalent orientation or attitude has subsequently characterised the local state elite's belief system with regard to the implementation of decentralisation and regional autonomy policies.

According to Hidayat (2003), in Indonesia today, the emergence of the so called Otonomi Daerah Kebablasan (over-reacted regional autonomy) may be seen as one of the logical consequences of that ambivalent orientation towards the implementation of decentralisation and regional autonomy policies. At a practical level, the ambivalent orientation and attitude towards the implementation of decentralisation and regional autonomy polices has been reflected by, for instance, the attitude of almost all local governments that tend to hold the central government as the major source of both the political and economic energies needed. Meanwhile, on the other hand, the local governments seem to have openly resisted, or even refused, central government's incursion upon areas of authority that have been designated as belonging to each individual local government. It is, in this context, Hidayat (2003) argues, that we can come to a theoretical explanation for understanding the mushrooming of the so called 
Perda Bermasalah (misintroduced Local Government Regulations) which took place in Indonesia in the last two years.

The third characteristic of decentralisation and regional autonomy practices in the so called period of transition towards democracy, according to Hidayat (2003), is that members of the society cannot be fully excluded from the implementation of the decentralisation process anymore. They have hitherto been involved in both policy making and policy implementation at local government level. However, in accordance with the features of a political system in a so-called period of transition towards democracy, the involvement of society is limited to representation by a few members of the societal elite. They are the ones who usually act on behalf of civil society and claim that they carry with them the societal interests. In a more specific term, it may therefore be argued that the inclusion of society in this sense does not take the form of "popular participation". Instead it is in the form of societal elite's participation. In essence, this means the pattern of state-society relationship with regard to the implementation of decentralisation and regional autonomy policies was characterised by the interaction between local state elite and societal elite. As a consequence, it is obvious that the collusion and bargaining of interests among the elite have become the prevailing feature of the political process at the local government level. This has not only taken place in the process of policy making but has also occurred at the policy implementation level.

Overall, when the three main features of the decentralisation and regional autonomy policies in the period of transition towards democracy outlined by Hidayat (2003) are viewed in the context of the fieldwork findings in West Java and West Sumatra, it becomes apparent that the third concluding remark proposed by this study has explicitly supported Hidayat's last proposition. This is perhaps, if there is a need to emphasise, one of the distinctive contributions of this paper to the academic debate, namely: it shares the work of those who have endeavoured to conceptualise the characteristics of decentralisation and regional autonomy policies in the so called epoch of "transition towards democracy".

\section{CLOSING REMARKS}

Theoretically, it is often mentioned that individual perception over an object has a strong impact on his or her behavior in both making and implementing such decision. This means to imply that individual political belief is to become one of determinant factor for individual political conduct (Almond (1974; Alagappa, 1995; Bate, 1981; Liddle, 1996; and Hidayat, 2005).

An appreciation to the above theoretical argument, and by taking into account a series of conclusions generated from the research finding, this paper finally suggests that: to understand better the features of Indonesian decentralization and regional autonomy on a day-to-day basis, scholars should pay more attention on the factors which directly or indirectly influence the 
behavior of local state elites in exercising local governments authority. Amongst these determinant factors are local state elites' perception of decentralization and regional autonomy, and the way in which this belief system has been shared with others.

\section{REFERENCES}

Alagappa, M. (1995). Political Legitimacy in Southeast Asia. California: Stanford University Press.

Almond, G. (ed). (1974). Comparative Politics Today: A World View, Boston: Little, Brown and Company.

Bates, R.. (1981). Market and State in Tropical Africa, Berkeley, CA: University of California Press.

Cheema, G.S. and Rondinelli, G.A. (eds). (1983). Decentralisation and Development: Policy Implementation in Developing Countries, Beverly Hills: Sage.

Hidayat, S. (1999). DECENCTRALISED POLITICS IN A CENTRALISED POLITICAL SYSTEM: A Study of Local State Power in West Java and West Sumatra in New Order Indonesia, Adelaide: Flinders University (Ph.D. Thesis)

Hidayat, S. (2000). Refleksi Realitas Otonomi Daerah dan Tantangan Ke Depan, Jakarta: Pustaka Quantum

Hidayat, S. (2003). "Desentralisasi dalam Perspektif State-Society Relation: Rekonstruksi Konsep dan Pendekatan Kebijakan, in Tim LIPI, Desentralisasi dan Otonomi Daerah: Naskah Akademik dan RUU Usulan LIPI, Jakarta: Pusat Penelitian Politik-LIPI dan Partnership for Governance Reform in Indonesia

Kasfir N. (1987). Designs and Dilemmas: An Overview, in Mawhood, P. (ed) (1983) Local Government in The Third World: The Experience of Tropical Africa, Chichester: John Wiley \& sons.

King, D.Y. (1988). Civil Service Policies in Indonesia: an Obstacle to Decentralisation? Public Administration and Development, Vol. 8, No.3.

King, D.Y.(1982) Indonesia's New Order as a Bureaucratic Polity, a Neopatrimonial Regime, or Bureaucratic Authoritarian Regime: What Difference Does it Make? in Anderson, B \& Kahin, A. (eds) Interpreting Indonesian Politics: Thirteen Contributions to the Debate, Ithaca: Cornell Modern Indonesia Project.

Legge, J.D. (1963). Central Authority and Regional Autonomy in Indonesia: A Study in Local Administration 1950-60, New York: Cornell University Press.

Liddle, R.W. (1988). Indonesia in 1987: The New Order at the Height of Its Power, Asian Survey, Vol. XXVIII, no.2 (February).

Liddle, R.W. (1992). The Politics of Development Policy, World Development, Vol. 20, no.6 (June). 
Liddle, R.W. (1996a). Improvising Political Culture Change: Three Indonesian Cases, in Liddle, R.W. (1996) Leadership and Culture in Indonesian Politics, Sydney: Asian Studies Association of Australia in Association with Allen \& Unwin.

Liddle, R.W. (1996b). The Relative Autonomy of the Third World Politician: Suharto and Indonesian Economic Development in Comparative Perspective, in Liddle, R.W. Leadership and Culture in Indonesian Politics, Sydney: Asian Studies Association of Australia in Association with Allen \& Unwin.

Maryanov, G.S. (1959). The Establishment of Regional Government in The Republic of Indonesia. Indiana University.

Mathur, K. (1983). Administrative Decentralisation in Asia, in Cheema, G.S. and Rondinelli, D.A. (eds) (1983) Decentralisation and Development: Policy Implementation in Developing Countries, Beverly Hills: Sage.

Mawhood P. (ed) (1987). Local Government in The Third World: The Experience of Tropical Africa, Chicheser: John Wiley \& Sons.

Morfit, M. (1986). Strengthening the Capacities of Local Government: Policies and Constraints, in MacAndrew (ed) Central Government and Development in Indonesia, Singapore: Singapore University Press.

Rondinelli, D.A. (1983) Implementing Decentralization Programmes in Asia: a Comparative Analysis, Public Administration and Development, Vol. 3.

Rondinelli, D.A. (1990) Decentralisation, Territorial Power and the State: A Critical Response, Development and Change, Vol. 21 (pp.491-50o).

Rondinelli, D.A. et al (1989) Analyzing Decentralization Policies in Developing Countries: a Political-Economy Framework, Development and Change, Vol. 20, No.1.

Schiller, J. (1986). State Formation in New Order Indonesia: The Powerhouse State in Jepara. PhD thesis, Monash University.

Schiller, J. (1990). State Formation and Rural Transformation: Adapting to the New Order' in Jepara, in Arif Budiman (ed.) State and Civil Society in Indonesia, Australia: Centre for South Asia Studies, Monash University.

Schiller, J. and Schiller B.M. (eds) (1997). Imagining Indonesia: Cultural Politic and Political Culture, USA: Center for International Studies, Ohio University.

Slater, D. (1989). Territorial Power and The Peripheral State: issue of Decentralization, Development and Change, Vol. 20, No.3.

Slater, D. (1990). Debating Decentralisation: A Reply to Rondinelli, Development and Change, Vol. 21 (pp.501-512).

Smith, B.C. (1985) Decentralization: The Territorial Dimension of the State, London: George Allen \& Unwin.

Smith, B.C. (1986). Spatial Ambiguities: Decentralisation within the State, Public Administration and Development, Vol. 6 (pp.455-465). 